\title{
PERMASALAHAN PENDIDIKAN DI INDONESIA UNTUK MENINGKATKAN MUTU DAN PROFESIONALISME GURU
}

\author{
Mila Gusnita \\ e-mail: milagusnita21@gmail.com
}

\begin{abstract}
ABSTRAK
Tujuan artikel ini adalah untuk mengidentifikasi permasalahan pendidikan di Indonesia.Dengan mengetahui permasalahan pendidikan yang ada diharapkan dapat dibuat suatu kebijakan yang sesuai untuk meningkatkan mutu dan profesionalisme guru.Pendidikan sebagai suatu sistem terbuka tidak lepas dari masalah, baik masalah mikro ataupun masalah makro. Masalah mikro, yaitu masalah yang timbul dalam komponen komponen yang terdapat dalam pendidikan itu sendiri sebagai suatu sistem, antara lain masalah kurikulum, masalah pendidikan, administrasi pendidikan dan sebagainya. Masalah makro, yaitu masalah yang muncul dalam pendidikan itu sebagai suatu sistem dengan sistem sistem lainnya yang lebih luas didalam seluruh kehidupan manusia, antara lain masalah kurang meratanya pendidikan, rendahnya mutu pendidikan, masalah efisiensi, relevansi dan lain lain. Berkaitan dengan permasalahan yang sering terjadi di Indonesia, guru dianggap sebagai sumber dari permasalahan tersebut, sehingga dengan mengidentifika si permasalahan pendidikan kita mengetahui letak permasalahan yang sebenarnya dan berusaha untuk memberikan solusi dari permasalahan tersebut.
\end{abstract}

\section{Kata kunci : Masalah Pendidikan, Mutu, Profesionalisme Guru}

\section{LATAR BELAKANG}

Pendidikan sebagai suatu sistem terbuka tidak lepas dari masalah, baik masalah mikro ataupun masalah makro. Masalah mikro, yaitu masalah yang timbul dalam komponen komponen yang terdapat dalam pendidikan itu sendiri sebagai suatu sistem, antara lain masalah kurikulum, masalah pendidikan, administrasi pendidikan dan sebagainya. Masalah makro, yaitu masalah yang muncul dalam pendidikan itu sebagai suatu sistem dengan sistem sistem lainnya yang lebih luas didalam seluruh kehidupan manusia, antara lain masalah kurang meratanya pendidikan, rendahnya mutu pendidikan, masalah efisiensi, relevansi dan lain lain. Berkaitan dengan permasalahan yang sering terjadi di Indonesia, guru dianggap sebagai sumber dari permasalahan tersebut, sehingga dengan mengidentifikasi 
permasalahan pendidikan kita mengetahui letak permasalahan yang sebenarnya dan berusaha untuk memberikan solusi dari permaslahan tersebut.

Sejalan dengan kondisi peringkat pendidikan Indonesia dibandingkan negaranegara lain di dunia, banyak faktor yang menentukan keberhasilan dari peserta didik, mulai dari sarana dan prasarana sekolah, kondisi ekonomi orang tua, Peran Pendidik, lingkungan belajar, lingkungan keluarga, faktor psikis dari peserta didik dan masih banyak faktor yang lainnya. Dari sekian banyak faktor yang mempengaruhi keberhasilan peserta didik yang paling berperan adalah pendidik dalam hal ini adalah guru.Guru yang notabene sebagai pengayom dan pemberi contoh bagi siswanya sangatlah penting sebagaimana diketahui bahwa semboyan guru "digugu lan ditiru" yang artinya orang yang dipercaya dan diikuti sebagai teladan.Kepercayaan yang diberikan kepada guru inilah yang henkadnya menjadi penyemangat dan stimulus agar guru selalu meningkatkan mutu dan profesionalismenya.

Di dalam Undang-undang Nomor 14 Tahun 2005 tentang Guru dan Dosen, terdapat empat kompetensi dimana masing masing harus dimiliki seorang guru. Komponen tersebut adalah kompetensi pedagogik, kepribadian, profesional, dan kompetensi sosial.Berdasarkan data dari Kementerian Pendidikan dan Kebudayaan (2015) uji kompetensi guru masih menunjukkan hasil yang kurang memuaskan dan masih perlu ditingkatkan untuk menembus tujuan standar pelayanan pendidikan untuk kompetensi guru.Tujuan penulisan ini adalah untuk mengidentifikasi permasalahan pendidikan di Indonesia.

\section{PEMBAHASAN}

\section{Masalah Masalah Pokok Pendidikan Saat Ini}

\section{Masalah pemerataan pendidikan}

Masalah pemerataan pendidikan, dimana isu ini berkaitan dengan sistem pendidikan seyogyanya menyiapkan peluang yang sangat besar bagi seluruh masyarakat agar dapat mengakses pendidikan, yang mana mampu menjadi tempat bagi keberlanjutan peningkatan SDM di Indonesia.

Menurut Wayan (1992) pemerataan pendidikan yang berkaitan dengan mutu proses dan hasil pendidikan belumlah merata di Indonesia. Masih banyak terdapat gap yang cukup besar pada penyelenggaraan pembelajaran pendidikan baik di kota 
maupun di desa, lebih khusus lagi bila dibandingkan daerah Jawa dan daerah Timur Indonesia. Apabila diamati lebih seksama dalam kurun waktu 10 tahun terakhir masih dirasa belum berhasil Pendidikan secara keseluruhan dapat meningkatkan kualitas hasil belajar sebagaimana pendapat Idris (1992:61-62) yang mana banyak peserta didik mempunyai kemampuan yang sedang/kurang dalam hasil belajar.

Ada banyak cara dapat dilakukan pemerintah untuk mengatasi masalah pemerataan pendidikan. Mulai dari cara konvensional sampai dengan cara inovatif. Adapun untuk cara tradisonal pemerintah dapat melakukan: Pertama dengan membangun gedung sekolah dan ruang belajar dan kedua memanfaatakan sekolah dengan sistem double sift (siswa dibagi kelas pagi dan sore). Adapun cara kedua yaitu cara inovatif dengan membangun sistem pamong (pendidikan bekerjasama dengan masyarakat), membangun sekolah di daerah terpencil dan mengirimkan guruguru untuk mendidik didaerah tersebut (pola SM3T), pola pendekatan rumah (guru mendatangi rumah siswa), Program Kejar Paket, Pembelajaran jarak j auh seperti yang diterapkan pada Universitas Terbuka.

\section{Masalah Mutu / Kualitas Pendidikan}

Mutu pendidikan sangatlah luas cakupannya, banyak yang hanya melihat dari kualitas luarannya. Apabila kita sadari proses belajar yang baik akan menghasilkan luaran yang baik pula, maka jika proses belajarnya kurang baik maka mutu hasil yang diharapkan akan kurang baik juga. Jika teqadi pembelajaran yang kurang optimal hal ini mengakibatkan nilai tes yang baik, sehingga bisa dikatakan hasil belajar itu semu.Hal ini mengindikasikan terdapat masalah pada kualitas pendidikan yang berkaitan dengan "pemrosesan" pembelajaran.

Proses pembelajaran berjalan dengan baik apabila didukung oleh berbagai unsur pendidikan diantaranya tenaga pendidik, peserta didik, sarana pembelajaran, kurikulum bahkan lingkungan sekitar. Sebagai contoh apabila unsur sarana yang ada di sekolah tersebut lengka, Sedangkan tenaga pendidik kurang terampil, hal ini menyebabkan kurang optimalnya proses pembelajaran dalam rangkan meningkatkan kualitas dan hasil belajar.

Solusi yang bisa ditawarkan untuk meningkatkan mutu pendidik diantaranya: (1) seleksi yang ketat untuk penerimaan mahasiswa calon pendidik; (2) Pengembangan 
keteramilan tenaga pendidik melalui pelatihan-pelatihan; (3) penyempurnaan kurikulum yang materinya disesuaikan dengan muatan lokal di daerah setempat; (4) pengembangan sarana dan prasaran yang dapat menciptakan suasana belajar yang nyaman; (5) penyempurnaan administrasi sekolah sehingga dapat efisiensi anggaran; (6) pengorganisasian dalam rangka untuk menjaga kualitas penyelenggara pendidikan perlu ditetapkan dengan didukung oleh lembaga yang sudah diberi wewenang dalam menjamin mutu diantaranya Lembaga Penjamin Mutu Pendidikan, dari Badan Akreditasi Nasional Sekolah Madrasah (BAN-SM) maupun dari lembaga independen.

\section{Masalah Efisiensi}

Membahas tentang efisiensi dalam sistem pendidikan dimana erat kaitannya dengan pemanfaatan segala kekuatan yang dimiliki agar tercapai misi yang rencanakan.Apabila dalam penggunaanya hemat dan cermat maka bisa disimpulkan bahwa tingkat efisiensinya tinggi.Tetapi apabila terjadi sebaliknya, maka efisiensinya dikatakan kurang.

Masalah ini meliputi : (1) kesenjangan antara lulusan dan lapangan kerja, dimana lulusan atau angkatan keqa lebih tinggi dari lapangan pekeqaan sehingga banya yang tidak terserap; (2) Beberapa daerah masih banyak guru yang mengajar diluar bidang keahlianya dan sukarnya untuk membuat guru mau mengabdi di daerah perbatasan maupun yang minim akses ke kota juga kurangnya insentif yang diberikan; (3) Pengembangan tenaga pendidik yang kurang cepat seperti perubahan kurikulum baru, sehingga banyak guru-guru yang belum siap menerima kurikulum baru; (4) Distribusi dan penggunaan sarana pembelajaran bila tidak diimbangi dengan kemampuan yang handal dari penggunanya mengakibatkan tejdi masalah di lapangan. Kemudian perubahan kurikulum yang menyebabkan buka lama tidak terpakai.

\section{Permasalahan Guru dan Pemecahannya}

Paradigma sekolah sudah banyak berkembang dari dulu hingga saat ini. Dulu sebuah sekolah sudah bisa menjalankan kegiatan pembelajaran apabila terdapat siswa, guru dan ruangan untuk proses pembelajaran dengan peralatan dan sarpras seadanya. Guru juga dijadikan sebagai sumber utama.la dijadikan sebagai sumber ilmu. Tugasnya mengalirkan pengetahuan ke siswa. Bagaimana yang dikemukakan 
oleh Sabandi (Sabandi, 2013) Guru melaksanakan tugas sesuai dengan prosedur operasional yang standar. Supervisor dengan guru merupakan dua pihak sebagai atasan-bawahan. Supervisor memil iki tingkat kebenaran yang lebih tinggi dari pada guru.f

Hal tersebut untuk saat ini sudah sudah tidak relevan dimana tugas guru sudah tidak menjadi penceramah yang harus selalu berdiri di depan siswa dan menjelasakan materi semua. Melainkan peran guru sudah berubah dimana tugsa guru menjadi fasilitator, mediator motivator guna menumbuhkan kreativitas dan daya imajinasi yang bagus siswa. Peraturan menteri pendidikan dengan membangkitkan budaya baca patut diberi apresiasi dimana siswa pada jam pertama dianjurkan untuk membaca buku bacaan apasaja.

Masalah penempatan guru, khususnya dalam penempatan studi, sering mengalami permasalahan yaitu guru ditempatkan tidak sesuai dengan bidangnya. Sebagai contoh ada sekolah yang diberikan guru baru tetapi untuk mata pelaj aran yang bersangkutan sudah penuh dan beliau harus mengajar mata pelajaran lain diluar keahliannya. Ada juga guru yang merangkap mengajar misalnaya guru Matematikajuga mengajar kesenian.

Multi peran seorang guru yaitu: melakukan interaksi dan pendeketan khusus dengan siswanya. Perhatian kepada siswa secara klasikal dan individu harus dikuasai oleh guru, dimana tugas guru pada saat memberikan motivasi dan mengarahkan siswa tidak boleh memelih siswa tertentu misalkan guru hanya memperhatikan siswa yang pandai, sementara siswa yang kurang pandai tidak diperhatikan. Guru hendaknya memberikan perhatian yang sama dengan selalu menanamkan rasa tanggungjawab, disiplin, percaya diri, menghargai pendapat teman dan pendidikan karakter lainnya.

Dalam segi pembelajaran guru diharapkan dapat: sebagai pengembil keputusan dalam pembelajaran (sebagai manager), memberikan arah pembelaj aran (director), mengorganisasi kegiatan pembelajaran (organisator), mengkoordinasikan semua pihak yang terlibat dalam proses pembelajaran (koordinator), mengkomunikasikan murid dengan berbagai sumber belajar (komunikator), menyediakan dan memberikan kemudahan-kemudahan belajar (fasilitator), memberikan dorongan belajar 
(stimulator). Kebanyakan guru belum mampu untuk melakukan multi perannya itu karena kebanyakan sekolah, guru adalah pejuang tunggal, yaitu guru merupakan sumber belajar, sebagai pusat tempat bertanya dan juga penempatan guru yang tidak sesuai dengan bidangnya sehingga banyak guru yang merangkap mengajar.

\section{SIMPULAN}

Berdasarkan Pemaparan di atas dapat disimpulkan bahwa ada empat poin yang dapat diuraikan berkaitan dengan identifikasi permasalahan pendidikan.Pertama masalah pemerataan pendidikan, masalah kualitas pendidikan, dan masalah efisiensi.

Dengan mengetahui faktor permasalahan pendidikan tersebut ada beberapa solusi yang ditawarkan untuk meningkatkan mutu dan profesinalisme guru diantaranya: (1) seleksi yang ketat untuk penerimaan mahasiswa calon pendidik; (2) Pengembangan keteramilan tenaga pendidik melalui pelatihan-pelatihan; (3) penyempurnaan kurikulum yang materinya disesuaikan dengan muatan lokal di daerah setempat; (4) pengembangan sarana dan prasaran yang dapat menciptakan suasana belajar yang nyaman; (5) penyempurnaan administrasi sekolah sehingga dapat efisiensi anggaran; (6) pengorganisasian dalam rangka untuk menjaga kualitas penyelenggara pendidikan perlu ditetapkan dengan didukung oleh lembaga yang sudah diberi wewenang dalam menjamin mutu diantaranya Lembaga Penjamin Mutu Pendidikan, dari Badan Akreditasi Nasional Sekolah Madrasah (BAN-SM) maupun dari lembaga independen.

\section{SARAN}

Artikel ini masih memiliki banyak kekurangan, baik dari segi data yang di tampilkan maupun dari segi informasi yang didapatkan masih jauh dari kesempurnaan. Penulis akan memperbaiki makalah dengan berpedoman pada banyak sumber yang dapat dipertanggungjawabkan. Maka dari itu penulis mengharapkan kritik dan saran menegnai pembahasan makalah dalam kesimpulan di atas.

\section{REFERENSI}


Idris, HZ. (1992).Pengantar Pendidikan 2. Jakarta: Gramedia Widiasarana

Hasbullah, (2012).Dasar-dasar IImu pendidikan. Jakarta: Raja Grafindo

Pidarta, Prof. Dr. Made. 2004. Manajemen Pendidikan Indonesia.Jakarta:PT Rineka Cipta

Sabandi, A. (2013). SUPERVISI PENDIDIKAN UNTUK PENGEMBANGAN PROFESIONALITAS GURU SUPERVISI PENDIDIKAN UNTUK PENGEMBANGAN PROFESIONALITAS GURU BERKELANJUTAN Oleh: Pedagogi, Jurnal IImiah IImu Pendidikan, XIII(2), 1-9. Retrieved from http://ejournal.unp.ac.id/index.php/pedagogi/article/view/4275 
